\title{
Pollen morphology of rare species of Linum L. (Linaceae) from Poland
}

\author{
Magdalena Kluza-Wieloch ${ }^{1}$, Irmina Maciejewska-Rutkowska ${ }^{2 *}$, Wanda \\ Wójtowicz $^{3}$ \& Justyna Wiland-Szymańska ${ }^{3,4}$
}

\author{
${ }^{1}$ Department of Botany, University of Life Sciences in Poznań, Wojska Polskiego 71c, 60-325 Poznań, Poland \\ ${ }^{2}$ Department of Forest Botany, University of Life Sciences in Poznań, Wojska Polskiego 71c, 60-325 Poznań, Poland \\ ${ }^{3}$ Botanical Garden, Adam Mickiewicz University in Poznań, Dąbrowskiego 165, 60-594 Poznań, Poland \\ ${ }^{4}$ Department of Plant Taxonomy, Botanical Garden, Adam Mickiewicz University in Poznan, Dąbrowskiego 165, 60-594 Poznań, Poland \\ * corresponding author (e-mail: irminamr@up.poznan.pl)
}

\begin{abstract}
The aim of the study was to describe pollen morphology and its variability of four Linum species: L. perenne subsp. extraaxillare, L. hirsutum, L. flavum and L. austriacum, all derived from Poland, but occurring in few natural sites within the country. Light and scanning electron microscopy was used and statistical analyses of quantitative pollen traits were performed. All taxa shared pollen grains which were 3-zonocolpate, isopolar, radiosymmetric, spheroidal and medium to large in size. Grains were semitectate, with the sculptural elements of the exine as gemmae or clavae. Additionally, upper parts of gemmae and clavae had a microstriate pattern. Despite great similarity among the investigated Linum species in pollen morphology, distinguishing features were determined.
\end{abstract}

Key words: pollen morphology, Linum, Poland, LM, SEM, ANOVA, PCA, LSD test

\section{Introduction}

Linum L. is the main genus of the Linaceae family with up to 180 species growing in temperate and subtropical regions, especially in the Mediterranean Basin (Hickey \& King 1988; McDill et al. 2009). There are probably 37 species of the genus in Europe (including 9 provinsional, 1 external and 7 endemic) (Ockendon \& Walters 2001). In Poland, in turn, it is represented only by 5 species: L. catharticum L. (section Cathartolinum), L. flavum L. (section Styllinum), L. hirsutum L. (section Dasyllinum), L. austriacum L. (section Linum) and L. perenne L. subsp. extraaxillare (Kit.) Nyman (= L. extraaxillare Kit., section Linum) (Mirek et al. 2002).

L. catharticum occurs in the wild in almost all of Europe and it is the most common flax species in Polish flora. L. hirsutum and L. flavum have similar European ranges and they appear from northern and western parts of the continent through central countries, to the Balkans and Turkey in the South. Both species are rare in Poland and can mainly be found in the southern part of the country: L. flavum in the Małopolska upland, Lublin upland, Roztocze region and near Przemyśl; $L$. hirsutum, in turn, within Nidziańska basin, as well as in the geobotanical district of Miechów-Pińczów. The extensive range is also characteristic of $L$. austriacum, which, among others, grows naturally in central and southern Europe, in western Asia (Turkey and Iran) and north Africa. However, it is very rare in Poland and occurs naturally exclusively in the environs of the city of Przemyśl. Therefore, its sparse sites in northern Poland and Silesia are considered to be of anthropogenic origin. L. perenne subsp. extraaxillare is an endemic plant, noted in the Carpathians and mountains of the Balkan Peninsula. In Poland, it is only found in the Tatra Mts., especially above the thickets of the dwarf mountain pine (Piękoś-Mirkowa et al. 2000; Kaźmierczakowa et al. 2014; Ockendon \& Walters 2001; Piękoś-Mirkowa \& Mirek 2003; Mirek \& Piękoś-Mirkowa 2008).

Since 1950s, a lot of palynological studies on the Linum genus both in LM, SEM and TEM have been carried out. Pollen morphology of over $60 \%$ flax species has been studied (Erdman 1966; Ockendon 1971; 
Rogers \& Xavier 1971, 1972; Kuprianova \& Alyoshina 1978; Rogers 1980, 1982, 1985; Xavier et al. 1980; Dulberger 1981; Punt \& De Breejen 1981; Grigoryeva 1988; Moroz \& Tsymbalyuk 2005; Perveen \& Qaiser 2008; Chestler \& Raine 2010; Talebi et al. 2012; Lattar et al. 2012a, 2012b). As a rule, earlier research focused on a small number of species only and there was no thorough analysis on pollen morphology of the genus. Furthermore, pollen of many species with limited ranges has not been studied yet. There is still no data on variations in pollen morphology of the species already described.

When compared with most angiosperms, pollen grains of Linum are rather large. They are usually at least $45 \mu \mathrm{m}$ in diameter and in section Linastrum even $125 \mu \mathrm{m}$ (Xavier et al. 1980). Most often, they are trizonocolpate and rarely multiaperturate. The latter have probably evolved from those with triaperturate at least five times within this genus (Rogers \& Xavier 1972). According to Yunus \& Nair (1988), members of the Linaceae family have a very distinct pattern of pollen surface and specific structural uniqueness dissimilar to other related families. There is also a certain uniformity in the exine sculpture in the Linum making pollen grains easily distinguishable for the genus. However, individual species have got diverse sculpture processes, which can take various forms, as bacula, gemma, pila, verrucae, clavae or echinae (Talebi et al. 2012). Besides, presence of heterostyly in about $40 \%$ of Linum species is expressed in variation in pollen morphology. As a rule, pollen surface of short-styled plants comprises almost exclusively monomorphic projections, while in case of long-styled plants, pollen surface consists of clearly dimorphic ones. Then, on average, short-style specimens have got pollen grains of smaller size than long-style specimens (Rogers 1980; Dulberger 1981; Punt \& Den Breejen 1981).

With the exception of the study by Stachurska and others (1963) on L. perenne subsp. extraaxillare (in LM), there are no reports on pollen morphology of the Linum genus from Poland.

The aim of the present study was to describe pollen morphology of the following four flax species: $L$. perenne subsp. extraaxillare, L. hirsutum, L. flavum and $L$. austriacum, derived from Poland and occurring in few natural sites within the country. Additionally, pollen variability of the above mentioned taxa was also analyzed to evaluate the potential systematic value of pollen traits in different geographic areas.

\section{Material and methods}

\subsection{Plant material}

Pollen samples were gathered from plants cultivated in the collection of the Botanical Garden of Adam Mickiewicz University in Poznań (Poland). The origin of the analyzed Linum species is: directly from natural populations (L. flavum from Żmudź reserve near Chełm Lubelski, Poland [AMUBG number R_R001_001_0025_7994_R008] and $L$. austriacum from Winna Góra near Przemyśl, Poland [R_R002_002_0012_7994_R009]) or from ex situ collections of botanic gardens $(\bar{L}$. hirsutum from Arboretum Bolestraszyce, Poland [R_R002_003_0002_7995 R005] and L. perenne from the Botanical Garden of M. Curie-Skłodowska University in Lublin, Poland [A_A007_000_0025_7010_A088]). For each species, anthers from 15 flowers were collected. Pollen samples were gathered randomly, without distinction between long- and short-styled forms of flowers. Such a method of pollen collection was applied intentionally to provide mean values of investigated traits for each species. The list of voucher specimens is deposited in the Department of Botany of University of Life Sciences in Poznań (Poland).

\subsection{Pollen morphological analyses}

Pollen viability was assessed with the standard method (Cresti \& Tiezzi 1992). For each investigated species, five anthers per five flowers were removed in the phase of pollination. Then pollen from anthers was transformed onto microscope slides containing a mixture of glycerol and 2\% acetic carmine (in the ratio 1:1). On the following day, slides with pollen were analyzed for viability. The percentage of stained pollen grains (viable) in relation to their total number was determined. For each species, 300 pollen grains were investigated.

For light (LM) and scanning electron microscopy (SEM), pollen grains were prepared according to the standard method described by Erdman (1966).

Table 1. Comparison of pollen viability of investigated Linum species

\begin{tabular}{lcc}
\hline Species & Percentage of viable pollen grains & Percentage of nonviable pollen grains \\
\hline L. perenne subsp. extraaxillare & 98.73 & 1.27 \\
L. austriacum & 94.12 & 5.88 \\
L. hirsutum & 97.87 & 2.13 \\
L. flavum & 95.33 & 4.67 \\
\hline
\end{tabular}



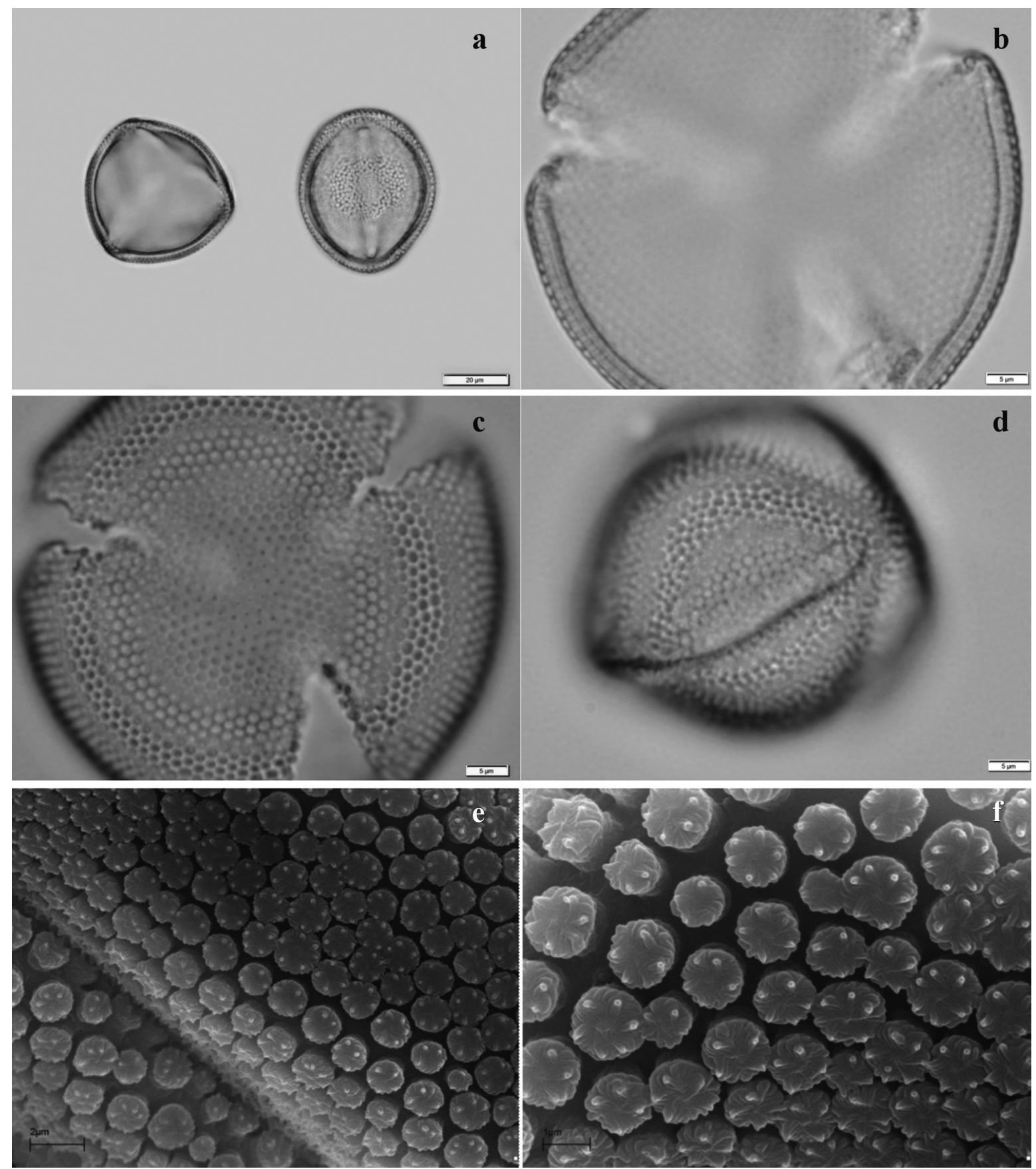

Fig. 1. Pollen morphology of Linum perenne subsp. extraaxillare

Explanations: a - outline in polar and equatorial views (LM), b - exine structure (LM), c- gemmate sculpture of apocolpium (LM), d-gemmate sculpture of mesocolpia (LM), e - exine sculpture in SEM, $\mathrm{f}$ - focus on gemmae (SEM). Scales, a - $20 \mu \mathrm{m}, \mathrm{b}-\mathrm{d}-5 \mu \mathrm{m}, \mathrm{e}-2 \mu \mathrm{m}, \mathrm{f}-1 \mu \mathrm{m}$

For LM, pollen grains were put into a drop of pure water and observations were made with the Olympus BX 43 microscope.

For SEM, samples of acetolysed grains were mounted on aluminum stubs, coated with gold in a sputter coater and examined with the Hitachi S3000N field emission scanning electron microscope at $5 \mathrm{kV}$ in the Institute of Plant Protection in Poznan (Poland) as well as with the Leo microscope belonging to the Department of Biology AMU in Poznań. Pollen terminology presented by Hesse et al. (2009) was used in this study.

\subsection{Statistical analyses}

Measurements of 30 grains for each specimen were taken and different traits were observed in polar and equatorial views ( $400 \mathrm{x}$ and $1000 \mathrm{x}$ ). Biometric results were statistically elaborated. The arithmetical mean, minimum, maximum, standard deviation (SD), variance and coefficient of variation (CV) were calculated. One factor of variance ANOVA was carried out to examine the significance of differences among mean values of the traits. The Least Significant Difference (LSD) test 

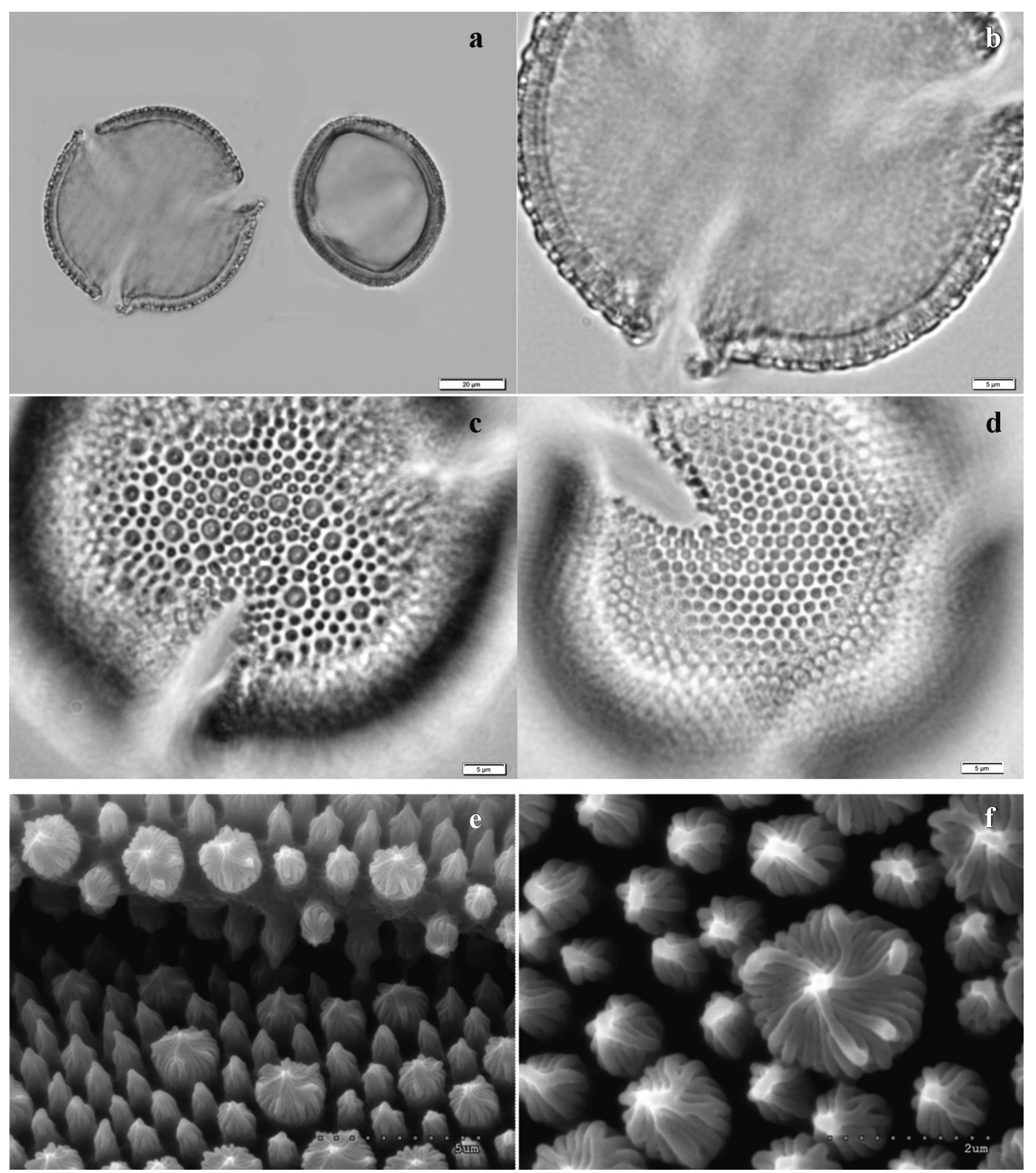

Fig. 2. Pollen morphology of Linum austriacum

Explanations: $a$ - outline in polar and equatorial views (LM), $b$ - exine structure (LM), $c$ - dimorphic sexine processes (LM), $d$ - monomorphic sexine processes (LM), e - exine sculpture in SEM, $\mathrm{f}$ - focus on gemmae (SEM). Scales, a $-20 \mu \mathrm{m}, \mathrm{b}-\mathrm{e}-5 \mu \mathrm{m}, \mathrm{f}-2 \mu \mathrm{m}$

was used to investigate the level of significance of the results. Tukey test for unequal numbers of observation was determined to find similar groups. The traits: lengths of $\mathrm{P}$ and $\mathrm{E}$ axes, $\mathrm{P} / \mathrm{E}$ ratio and exine thickness were examined in 30 repetitions for each species, while the number of exine processes and apocolpium diameter - in 15. An analysis of the correlation between the measured traits was done. With no prior assumptions, PCA principal component analysis was carried out to examine relationships among individuals from particu- lar samples. Means obtained from the analyses allowed creation of a dendrogram based on Euclidean distance and, thus, to demonstrate the degree of similarity among the investigated species (Sneath \& Sokal 1973).

\section{Results}

\subsection{Pollen morphological analyses}

In general, all analyzed Linum species were characterized by high viability of pollen grains (Table 1 ). The 

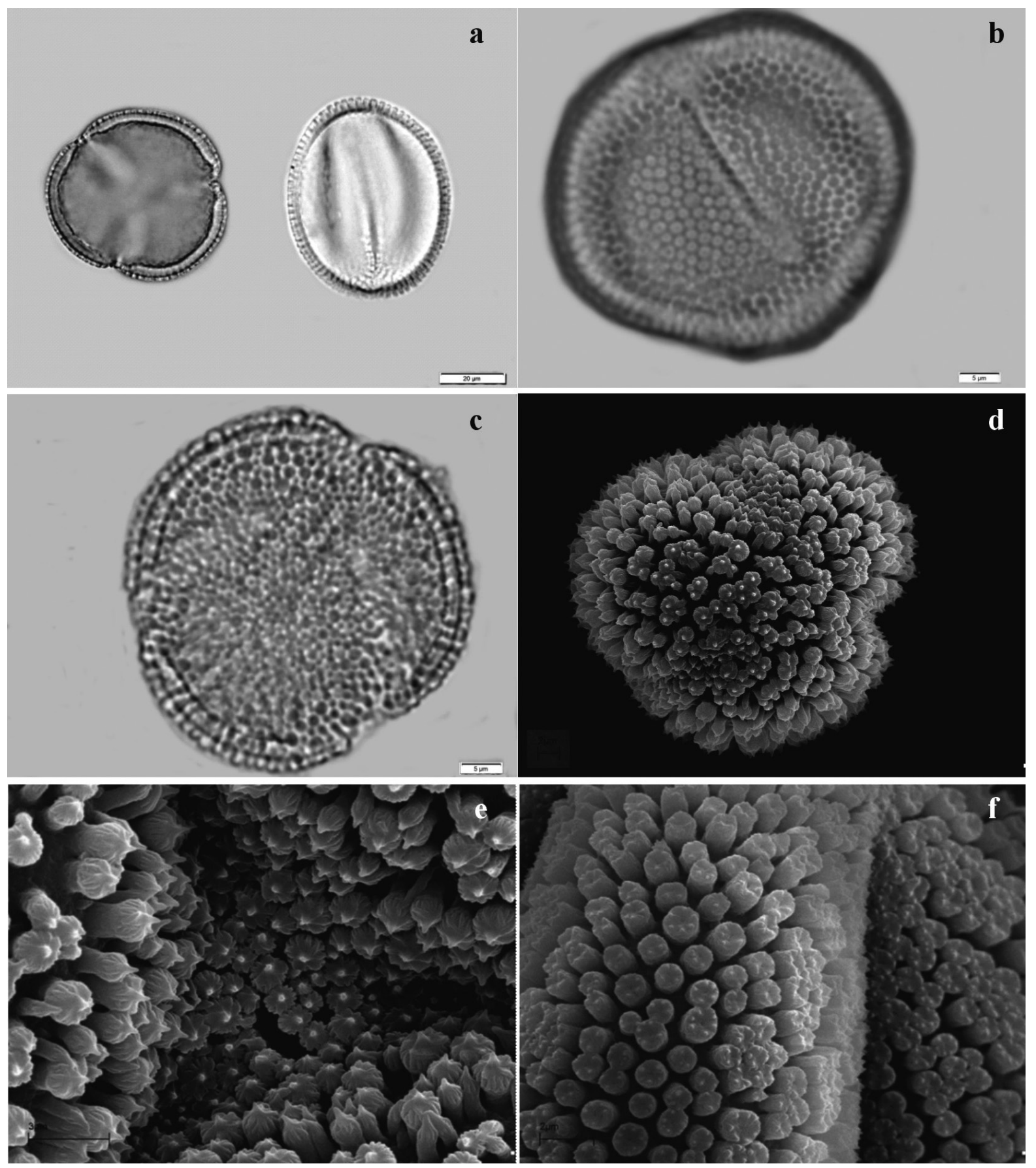

Fig. 3. Pollen morphology of Linum hirsutum

Explanations: $\mathrm{a}$ - outline in polar and equatorial views $(\mathrm{LM}), \mathrm{b}-$ monomorphic sexine processes $(\mathrm{LM}), \mathrm{c}-$ dimorphic sexine processes (LM), $d-$ clavate sculpture in SEM, $\mathrm{e}-$ focus on clavae within apocolpium (SEM), $\mathrm{f}-$ focus on clavae within mesocolpium (SEM). Scales, $\mathrm{a}-20 \mu \mathrm{m}, \mathrm{b}-\mathrm{c}-5 \mu \mathrm{m}, \mathrm{d}, \mathrm{f}-2 \mu \mathrm{m}, \mathrm{e}-3 \mu \mathrm{m}$

lowest percentage of dead grains - about $1.3 \%$ was found in the sample of $L$. perenne subsp. extraaxillare and the highest, but not exceeding $5.0 \%$ - in L. flavum. Pollen grains of all investigated species were 3-zonocolpate, isopolar, radiosymmetric and medium $(L$. hirsutum) to large size (L. austriacum, L. flavum and L. perenne subsp. extraaxillare). Most often, they were prolate-spheroidal in shape, with circular amb. The length of the colpus amounted to at least $3 / 4$ of the length of the polar axis. The exine was $2.8-5.3 \mu \mathrm{m}$ thick and the sexine and nexine were of similar thickness, or slightly thicker (sexine). Grains were semitectate. With LM, they had gemmate and clavate surface. Pollen grains were both with monomorphic and dimorphic processes (L. austriacum, L. flavum and L. hirsutum) or only monomorphic (L. perenne subsp. extraaxillare). With SEM, sculpture consisted of gemmae (L. perenne subsp. extraaxillare) or only exclusively of clavae ( $L$. austriacum, L. flavum and L. hirsutum). Gemmae were $\pm 0.5-1.3 \mu \mathrm{m}$ in height and $\pm 0.8-2.5 \mu \mathrm{m}$ in diameter $(L$. 

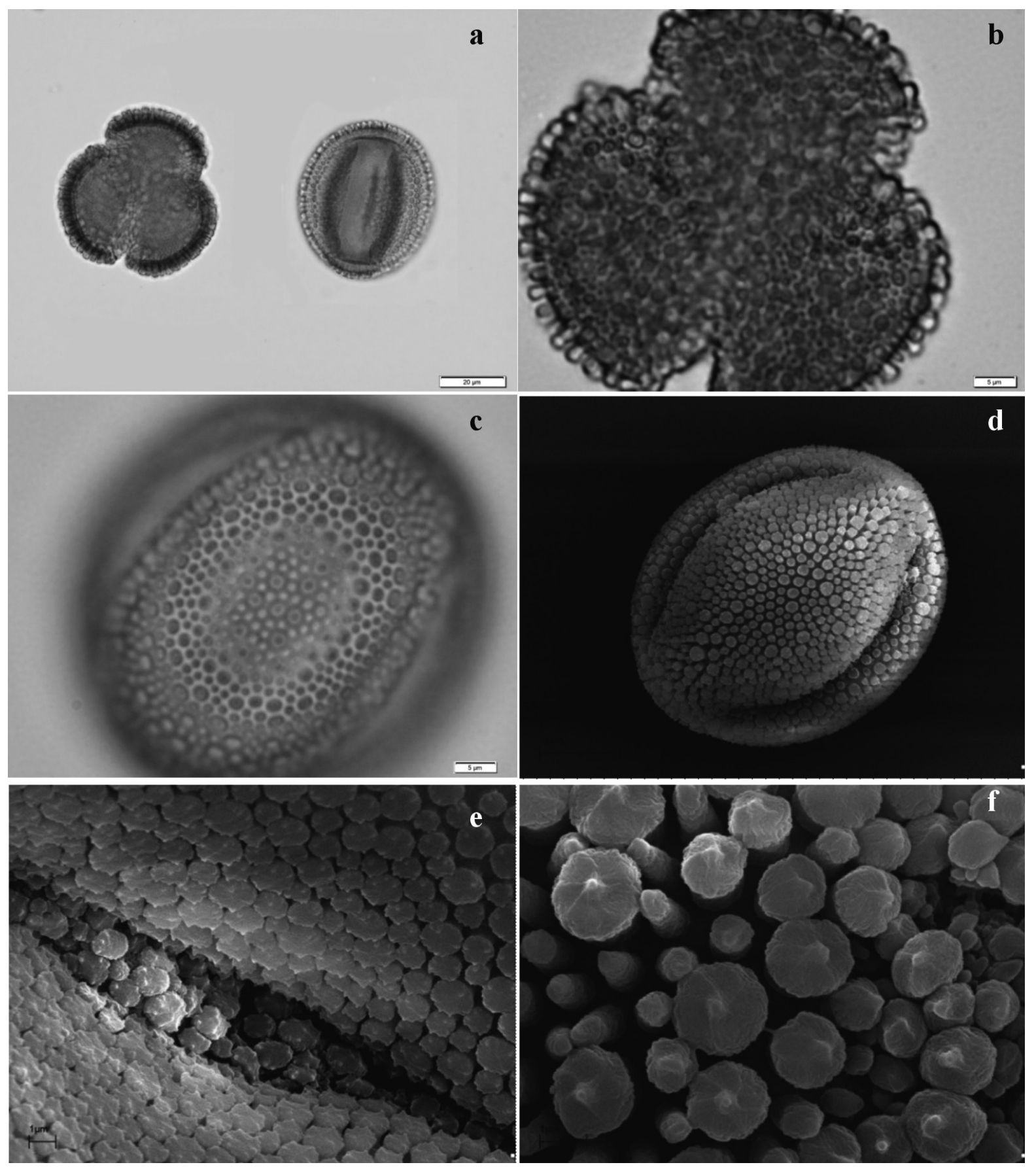

Fig. 4. Pollen morphology of Linum flavum

Explanations: $\mathrm{a}$ - outline in polar and equatorial views $(\mathrm{LM}), \mathrm{b}$ - apocolpium with dimorphic sexine processes $(\mathrm{LM}), \mathrm{c}-$ mesocolpium with dimorphic sexine processes (LM), $d$ - clavate sculpture in SEM, e - zone of colpus (SEM), $\mathrm{f}$ - focus on clavae within mesocolpium (SEM). Scales, $\mathrm{a}-20 \mu \mathrm{m}, \mathrm{b}-\mathrm{c}-5 \mu \mathrm{m}$, $\mathrm{d}-10 \mu \mathrm{m}, \mathrm{e}-\mathrm{f}-1 \mu \mathrm{m}$

perenne subsp. extraaxillare). Clavae were of $\pm 2 \mu \mathrm{m}$ (L. austriacum) to $\pm 3 \mu \mathrm{m}$ (L. flavum and L. hirsutum) in height and $\pm 0.7-2.1 \mu \mathrm{m}$ in diameter. Upper parts of gemmae and clavae showed a striate pattern. Striae were radially spread. Additionally, there were central and 5-6 perispherial rounded granules on tops of gemmae and clavae (L. perenne subsp. extraaxillare and L. austriacum) or only central granules were visible (L. flavum and L. hirsutum). Margins of colpi were regular, with the same sculpture as the adjacent area of mesocolpi. Specific features of the pollen grains of each investigated species are illustrated in the Figures 1-4.

On average, the largest pollen grains were noted in L. flavum and L. austriacum (Table 2). The smallest value of $\mathrm{P} / \mathrm{E}$ ratio was revealed in L. flavum (pollen grains most often spheroidal in shape). $\mathrm{P} / \mathrm{E}$ ratio in other species was usually more than 1.10 (grains mainly prolate-spheroidal). The thickest exine was observed in L. austriacum and L. perenne subsp. extraaxillare. On average, the widest mesocolpia were in L. perenne 
Table 2. Basic statistical characteristics of analyzed traits of four investigated Linum species

\begin{tabular}{|c|c|c|c|c|c|c|}
\hline Species & Mean & Minimum & Maximum & $\begin{array}{l}\text { Standard } \\
\text { deviation }\end{array}$ & Variance & $\begin{array}{l}\text { Coefficient } \\
\text { of variation }\end{array}$ \\
\hline \multicolumn{7}{|c|}{ Length of polar axis $\mathrm{P}(\mu \mathrm{m})$} \\
\hline L. hirsutum & 48.67 & 35.00 & 75.00 & 7.15 & 51.18 & 14.70 \\
\hline L. flavum & 61.17 & 40.00 & 70.00 & 6.56 & 42.99 & 10.72 \\
\hline L. austriacum & 61.92 & 52.50 & 70.00 & 4.29 & 18.40 & 6.93 \\
\hline \multirow{2}{*}{$\begin{array}{l}\text { L. perenne subsp. } \\
\text { extraaxillare }\end{array}$} & 51.58 & 27.50 & 62.50 & 8.42 & 70.90 & 16.32 \\
\hline & \multicolumn{5}{|c|}{ Length of equatorial axis $\mathrm{E}(\mu \mathrm{m})$} & \\
\hline L. hirsutum & 43.67 & 32.50 & 67.50 & 6.39 & 40.83 & 14.63 \\
\hline L. flavum & 56.92 & 35.00 & 67.50 & 7.30 & 53.31 & 12.83 \\
\hline L. austriacum & 56.33 & 47.50 & 65.00 & 4.39 & 19.28 & 7.79 \\
\hline \multirow{2}{*}{$\begin{array}{l}\text { L. perenne subsp. } \\
\text { extraaxillare }\end{array}$} & 46.67 & 22.50 & 60.00 & 8.31 & 69.11 & 17.81 \\
\hline & \multicolumn{5}{|c|}{$\mathrm{P} / \mathrm{E}$ ratio } & \\
\hline L. hirsutum & 1.12 & 1.05 & 1.29 & 0.07 & 0.00 & 5.93 \\
\hline L. flavum & 1.08 & 1.00 & 1.40 & 0.07 & 0.01 & 6.56 \\
\hline L. austriacum & 1.10 & 1.04 & 1.33 & 0.07 & 0.00 & 6.33 \\
\hline \multirow{2}{*}{$\begin{array}{l}\text { L. perenne subsp. } \\
\text { extraaxillare }\end{array}$} & 1.11 & 1.00 & 1.33 & 0.08 & 0.01 & 7.43 \\
\hline & \multicolumn{5}{|c|}{ Exine thickness $(\mu \mathrm{m})$} & \\
\hline L. hirsutum & 3.64 & 2.83 & 5.32 & 0.67 & 0.44 & 18.32 \\
\hline L. flavum & 3.60 & 3.02 & 4.27 & 0.37 & 0.14 & 10.24 \\
\hline L. austriacum & 3.88 & 2.94 & 4.76 & 0.49 & 0.24 & 12.63 \\
\hline \multirow{2}{*}{$\begin{array}{l}\text { L. perenne subsp. } \\
\text { extraaxillare }\end{array}$} & 3.98 & 3.19 & 5.16 & 0.40 & 0.16 & 10.15 \\
\hline & \multicolumn{5}{|c|}{ Width of mesocolpium $(\mu \mathrm{m})$} & \\
\hline L. hirsutum & 23.46 & 19.58 & 28.79 & 3.80 & 14.45 & 16.20 \\
\hline L. flavum & 23.04 & 19.70 & 24.94 & 1.77 & 3.15 & 7.70 \\
\hline L. austriacum & 20.47 & 15.89 & 24.93 & 2.92 & 8.53 & 14.27 \\
\hline \multirow{2}{*}{$\begin{array}{l}\text { L. perenne subsp. } \\
\text { extraaxillare }\end{array}$} & 32.43 & 22.97 & 36.58 & 5.39 & 29.10 & 16.63 \\
\hline & \multicolumn{5}{|c|}{ Number of exine processes per area of $100 \mu \mathrm{m}^{2}$} & \\
\hline L. hirsutum & 35.00 & 29.00 & 39.00 & 3.42 & 11.67 & 9.76 \\
\hline L. flavum & 41.43 & 34.00 & 59.00 & 8.46 & 71.62 & 20.43 \\
\hline L. austriacum & 41.86 & 39.00 & 48.00 & 3.13 & 9.81 & 7.48 \\
\hline \multirow{2}{*}{$\begin{array}{l}\text { L. perenne subsp. } \\
\text { extraaxillare }\end{array}$} & 40.86 & 35.00 & 47.00 & 3.98 & 15.81 & 9.73 \\
\hline & \multicolumn{5}{|c|}{ Apocolpium diameter $(\mu \mathrm{m})$} & \\
\hline L. hirsutum & 15.43 & 8.17 & 19.17 & 4.30 & 18.45 & 27.84 \\
\hline L. flavum & 19.01 & 11.84 & 26.18 & 5.47 & 29.91 & 28.78 \\
\hline L. austriacum & 16.98 & 8.68 & 22.85 & 4.73 & 22.33 & 27.83 \\
\hline $\begin{array}{l}\text { L. perenne subsp. } \\
\text { extraaxillare }\end{array}$ & 20.04 & 13.38 & 23.94 & 4.02 & 16.17 & 20.07 \\
\hline
\end{tabular}

subsp. extraaxillare and the shortest - in L. austriacum. The smallest number of exine processes per area of $100 \mu \mathrm{m}^{2}$ as well as the smallest apocolpium diameter was noted in L. hirsutum. Other species had a similar number of exine processes but their apocolpium area varied slightly in size. The apocolpium diameter was the most variable trait in all species and the most constant was $\mathrm{P} / \mathrm{E}$ ratio. There were no pollen traits with the larg- est or smallest values of coefficient of variation for all investigated species (Fig. 5).

\subsection{Statistical analyses}

The analysis of variance showed that all species were significantly determined by the length of the equatorial and polar axes, the exine thickness and the width of mesocolpium (Table 3). Least significant difference (LSD) 
Table 3. The results of variance analysis of 7 dependent variables and factors for the studied Linum species; $p<0.001$

\begin{tabular}{lccc}
\hline \multicolumn{1}{c}{ Traits } & $\mathrm{F}$ & $\mathrm{p}$ & partial eta-squared \\
\hline Length of P axis & $29.40653^{* * *}$ & 0.000000 & 0.431984 \\
Length of E axis & $29.79436^{* * *}$ & 0.000000 & 0.435202 \\
P/E ratio & 1.46467 & 0.227841 & 0.036497 \\
Exine thickness & $4.12368^{* *}$ & 0.008082 & 0.096369 \\
Width of mesocolpium & $13.82885^{* * *}$ & 0.000019 & 0.633513 \\
Number of exine & 2.66025 & 0.071023 & 0.249549 \\
processes & 1.37016 & 0.275759 & 0.146226 \\
Apocolpium diameter & & & \\
\hline
\end{tabular}

test and calculation of partial eta-squared revealed that the species were to the greatest extent explained by the width of mesocolpium and to the smallest - by P/E ratio.

Tukey's test for homogenous groups revealed that the lengths of $\mathrm{P}$ and $\mathrm{E}$ axes divided pollen of the investigated taxa into two inseparable groups - first with $L$. hirsutum and $L$. perenne subsp. extraaxillare and the other one with $L$. flavum, $L$. austriacum and $L$. perenne subsp. extraaxillare. The width of mesocolpium marked out two separable groups: one with L. hirsutum, L. flavum and $L$. austriacum and the other with $L$. perenne subsp. extraaxillare. The thickness of exine allowed identification of two inseparable groups: first with $L$. hirsutum, L. flavum andi L. austriacum and the other with $L$. perenne subsp. extraaxillare. According to other quantitative traits $-\mathrm{P} / \mathrm{E}$ ratio, number of exine processes and apocolpium diameter, all species formed a homogenous group.

Correlation analysis revealed a positive relationship between lengths of $\mathrm{P}$ and $\mathrm{E}$ axes, and a negative one between $\mathrm{P} / \mathrm{E}$ ratio and the length of $\mathrm{E}$ axis. Other traits were not significantly correlated (Table 4). The analysis of the percentage of explained variance revealed that the first principal component PC1 explained $30.05 \%$ of the observed variability and the other principal component PC2 elucidated $19.79 \%$ (Fig. 6). A strong correlation, positively associated with $\mathrm{PC} 1$ factor, was proved between the lengths of $\mathrm{P}$ and $\mathrm{E}$ axes. Furthermore, we discovered a weaker and a negative correlation between the length of $\mathrm{E}$ and $\mathrm{P} / \mathrm{E}$ ratio.

Similarly, the dendrogram constructed on the basis of Euclidean distances for the analyzed pollen samples showed close similarity between $L$. flavum and L. austriacum (Fig. 7). The second distinct group consisted of L. hirsutum and L. perenne subsp. extraaxillare; however, linkages were distinctly larger than in case of the first pair.

\section{Discussion}

Pollen quality is an important component of plant reproductive success. Its assessment is critical for many

Table 4. The correlation matrix among 7 analyzed traits for all investigated Linum species

\begin{tabular}{|c|c|c|c|c|c|c|c|}
\hline Trait & $\begin{array}{l}\text { Length of } P \\
\text { axis }\end{array}$ & $\begin{array}{l}\text { Length of E } \\
\text { axis }\end{array}$ & $\mathrm{P} / \mathrm{E}$ ratio & $\begin{array}{l}\text { Exine } \\
\text { thickness }\end{array}$ & $\begin{array}{l}\text { Width of } \\
\text { mesocolpium }\end{array}$ & $\begin{array}{l}\text { Number } \\
\text { of exine } \\
\text { processes }\end{array}$ & $\begin{array}{l}\text { Apocolpium } \\
\text { diameter }\end{array}$ \\
\hline $\begin{array}{l}\text { Length of } \mathrm{P} \\
\text { axis }\end{array}$ & 1 & & & & & & \\
\hline $\begin{array}{l}\text { Length of } E \\
\text { axis }\end{array}$ & $0.93565 * * *$ & 1 & & & & & \\
\hline $\mathrm{P} / \mathrm{E}$ ratio & -0.07906 & $-0.42093 * * *$ & 1 & & & & \\
\hline $\begin{array}{l}\text { Exine } \\
\text { thickness }\end{array}$ & 0.02008 & -0.00964 & 0.07041 & 1 & & & \\
\hline $\begin{array}{l}\text { Width of } \\
\text { mesocolpium }\end{array}$ & -0.19519 & -0.11845 & -0.12479 & 0.09021 & 1 & & \\
\hline $\begin{array}{l}\text { Number } \\
\text { of exine } \\
\text { processes }\end{array}$ & 0.34374 & 0.29187 & 0.05934 & 0.23239 & -0.00825 & 1 & \\
\hline $\begin{array}{l}\text { Apocolpium } \\
\text { diameter }\end{array}$ & 0.28539 & 0.34781 & -0.15830 & 0.06977 & 0.24804 & -0.25164 & 1 \\
\hline
\end{tabular}


aspects of pollination biology, as in studies on genetics, pollen-stigma interaction, gene bank or pollen biochemistry (Cresti \& Tiezzi 1992; Dafni \& Firmage 2000). Until now, pollen viability studies within Linaceae family have only referred to commonly cultivated $L$.
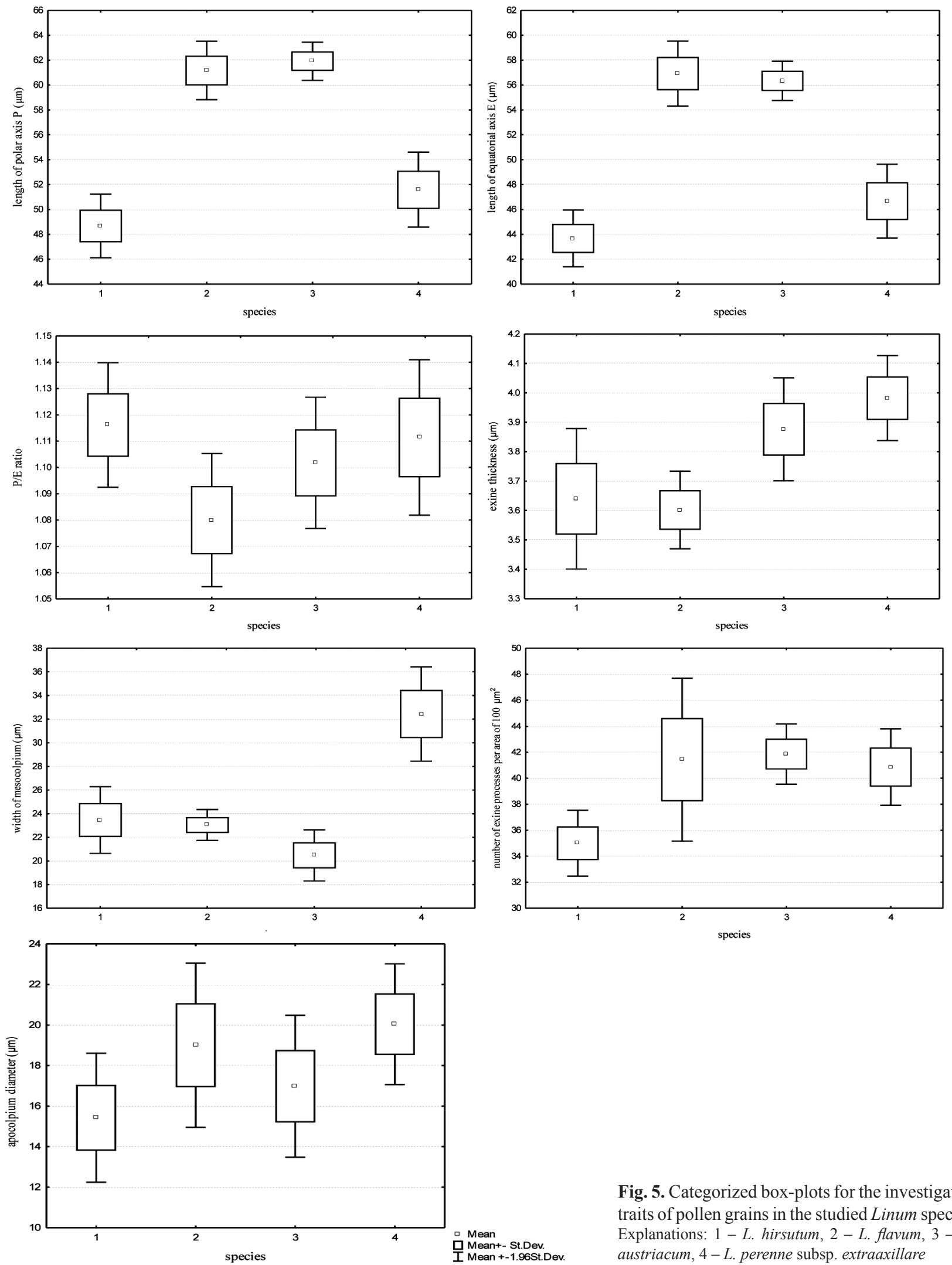

Fig. 5. Categorized box-plots for the investigated traits of pollen grains in the studied Linum species Explanations: $1-L$. hirsutum, $2-L$. flavum, $3-L$. austriacum, $4-L$. perenne subsp. extraaxillare 


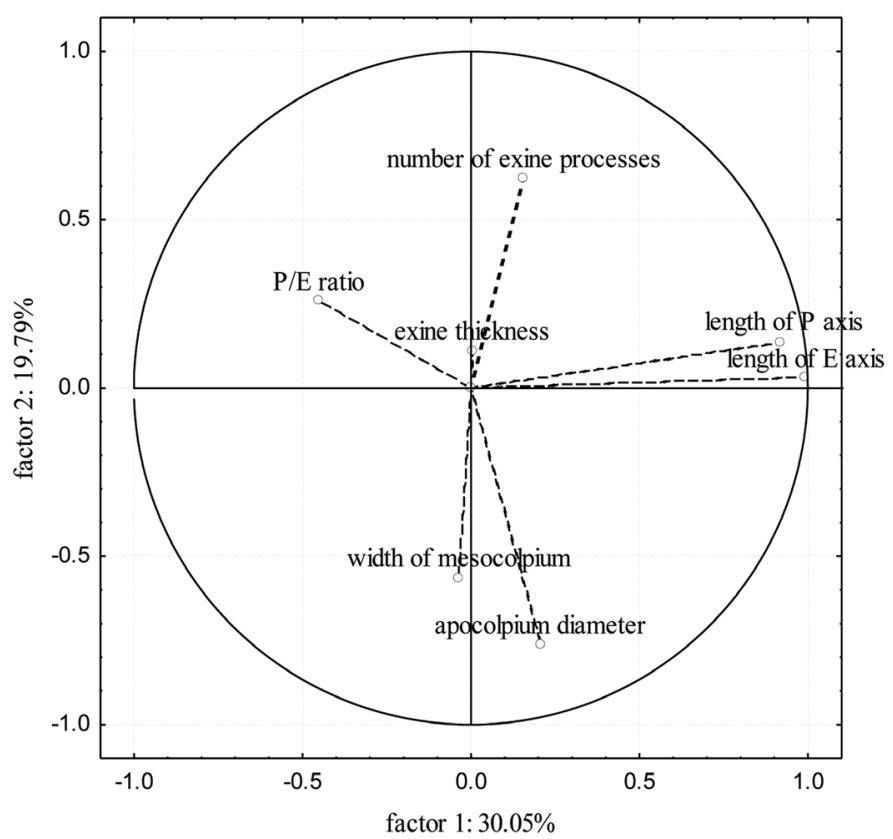

Fig. 6. Factor loadings of 7 analyzed traits of the studied Linum species

the smallest grains (L. hirsutum). In current research, however, all analyzed Linum taxa were characterized by very high viability of pollen grains.

Acccording to Punt \& Den Breejen (1981), several Linum species are characterized by compound apertures. They described pollen grains of $L$. austriacum with well-marked lolongate endocolpi, longer and wider than ectocolpi. Besides, the authors considered endoaperture to be sometimes faintly visible in pollen grains of L. flavum. The same opinion was expressed by Chestler \& Raine (2010), who analyzed pollen grains of L. austriacum and L. flavum from north-western Greece. However, those observations were not confirmed in any other study on these species (Grigoryeva 1988; Moroz \& Tsymbalyuk 2005; Talebi et al. 2012). Similarly, we observed grains of L. austriacum and L. flavum with only simple apertures.

In our current work, all analyzed species were distylous. Hence, their pollen should be differentiated morphologically, depending on participation level of long- and short-styled specimens in a given population (Rogers 1980; Dulberger 1981). Based on the works carried out so far, the most distinct differences in pollen size were observed in L. perenne subsp. extraaxillare, where polar axis of the grains was up to $10 \mu \mathrm{m}$ longer in long-styled specimens, than in those with short styles (Moroz \& Tsymbalyuk 2005). However, Punt \& Den Breejen (1981) assessed differences in the length of $\mathrm{P}$ axis between both forms of flowers of this species to be only about $5 \mu \mathrm{m}$. According to the cited authors, for the other three species, differences in $\mathrm{P}$ length between two forms of flowers did not exceed 3-6 $\mu \mathrm{m}$. Furthermore, axis length ranges of both forms in all analyzed species often overlapped. Therefore, the size of pollen grains does not seem to be an unambiguous diagnostic feature. On the basis of literature, average length of $\mathrm{P}$ axes in all

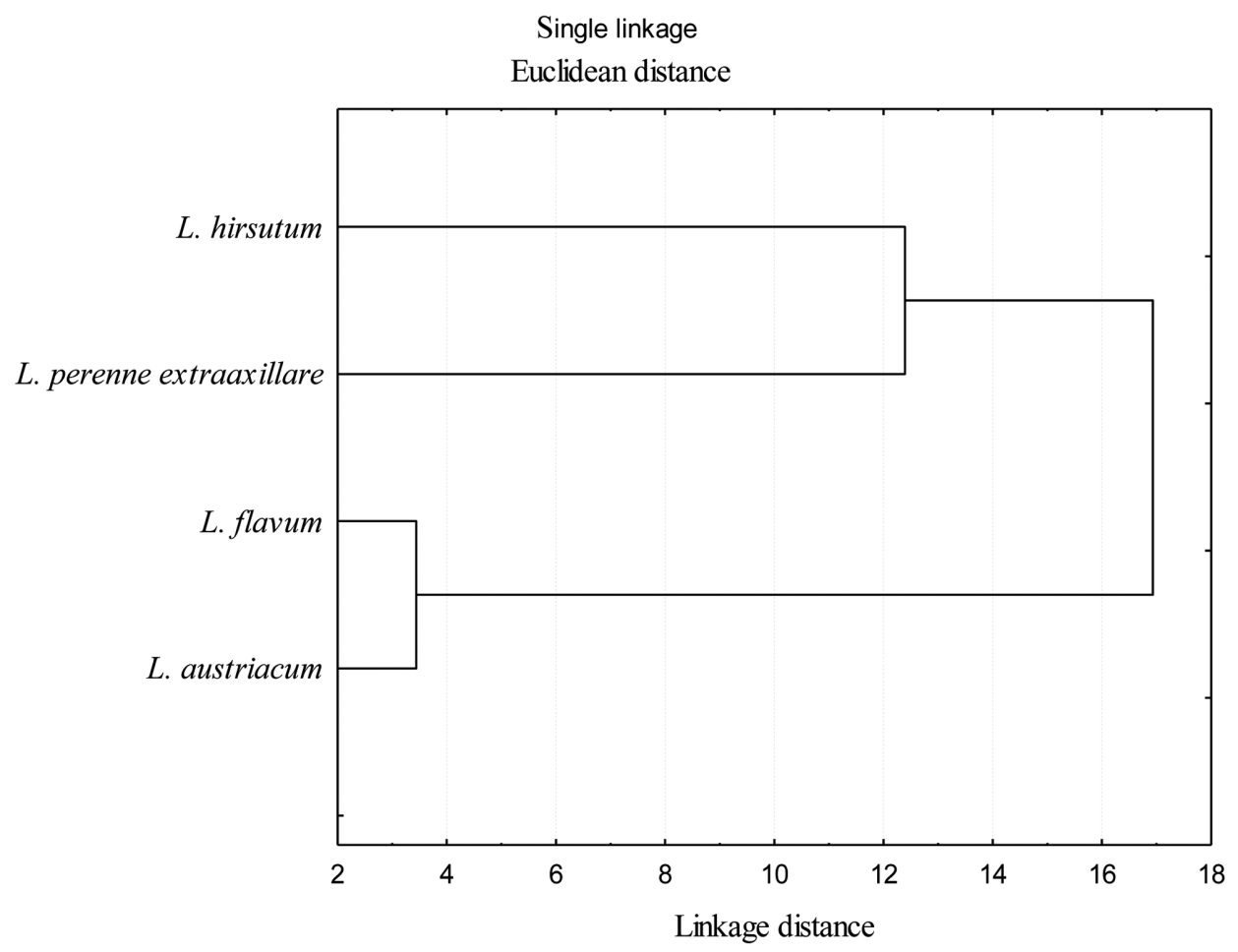

Fig. 7. Dendrogram constructed on the basis of the shortest Euclidean distances according to the single linkage method using 7 morphological traits of the studied Linum species 
investigated species in our current work corresponded to pollen grains from long-styled flowers.

It is widely believed that heterostyly is also reflected in a variation of exine sculpture of pollen grains (Kuprianova \& Alyoshina 1978; Rogers 1980). According to literature, this phenomenon was noticed in all currently analyzed species (Punt \& Den Breejen 1980; Grigoryeva 1988). In our present study, we observed distinct diversity of exine sculpture among pollen grains in the samples of L. hirsutum and L. austriacum, while pollen samples of $L$. flavum and $L$. perenne subsp. extraaxiliare were morphologically uniform. Based on properties of exine processes, pollen grains of L. flavum corresponded to pollen of long-styled flowers and of $L$. perenne subsp. extraaxillare - to pollen of short-styled flowers.

In palynological literature, exine processes of $L$. austriacum are both described as gemmae and clavae, in L. hirsutum - as verrucae and clavae and in L. perenne s.l. - as bacula and gemmae (Erdman 1966; Perveen \& Qaiser 2008; Chestler \& Raine 2010). On the other hand, in studies on pollen of some Linum species from Eastern Europe, individual terms were used without direct reference to universally recognized palynological dictionaries (Grigoryeva 1988; Moroz \& Tsymbalyuk 2005). On the basis of the current study, in pollen grains of the investigated species, we distinguished 2 types of exine processes: gemmae and clavae. Both exine elements were very similar in shape; however, they varied in size (Punt et al. 2007; Hesse et al. 2009).
The present study revealed some variation in pollen morphology of 4 Linum species. However, the investigated taxa exhibited many features in common, especially those related to the shape, amb, exine structure and apertures. Pollen of L. hirsutum was distinguished by smaller size and lower density of exine processes. Due to the sculpture, it resembled pollen of L. austriacum the most, but without distinct peripheral granules on the capita of exine processes. On the other hand, $L$. perenne subsp. extraauxilare was most similar to $L$. flavum, but its exine processes were shorter and took the form of gemmae (not clavae like in the other species). So, the current study revealed a small morphological similarity between two related species $-L$. austriacum and $L$. perenne subsp. extraauxilare - of the section Linum. This observation does not confirm Ockendon's opinion (1971), who, based on pollen morphology, distinguished $L$. perenne group consisting of very closely related species with, among others, L. austriacum and L. perenne subsp. extraauxilare.

This comprehensive study on pollen morphology of four Linum species is of practical importance for the use in dating fossil and subfossil materials from the area of Central Europe. More studies concerning differences in pollen in heterostylous species of the Linum genus in Poland are currently under way.

Acknowledgments. We would like to thank Dr Mirosława Sitek (Adam Mickiewicz University in Poznań) for the consultation on statistical results.

\section{References}

Chestler P. I. \& Raine J. I. 2010. Pollen and spore keys for Quaternary deposits in the northen Pidos Mountains, Greece. Grana 40(6): 297-387. http://dx.doi. org/10.1080/00173130152987535.

Cresti A. \& Tiezzi M. (eds.). 1992. Sexual plant reproduction. 246 pp. Springer, Verlag, Berlin, Heidelberg, New York.

Dafni A. \& Firmage D. 2000. Pollen viability and longevity: practical, ecological and evolutionary implications. Pl. Syst. Evol. 222: 113-132. http://dx.doi.org/10.1007/ BF00984098.

Dufay M., Vaudey V., De Cauner I., Touzet P., Cuguen J. \& ARNAUD J. F. 2008. Variation in pollen production and pollen viability in natural populations of gynodioecious Beta vulgaris ssp. maritima: evidence for a cost of restoration of male function? J. Evolution. Biol. 21: 202-212.
Dulberger R. 1981. Dimorphic exine sculpturing in three distylous species of Linum (Linaceae). Pl. Syst. Evol. 139: 113-119.

ERdman G. 1966. Pollen morphology and plant taxonomy. Angiosperms. 2nd edition. 539 pp. Hafner Publishing Company, New York, London.

Grigoryeva V. V. 1988. The pollen grain morphology in the genus Linum (Linaceae) of the flora of the USSR. Bot. Zhurn. SSSR. 73: 1409-1417.

Hesse M., Halbritter H., Zetter R., Weber M., Buchner R., Frosch-Radivo A. \& Urlich S. 2009. Pollen terminology: an illustrated handbook. 264 pp. Springer, New York, Wien.

Hickey M. \& King C. 1988. 100 families of flowering plants. 2nd edition. 619 pp. Cambridge University Press, Cambridge, New York. 
Kaźmierczakowa R., Zarzycki K. \& Mirek Z. (eds.). 2014. Polska Czerwona Księga Roślin. Paprotniki i rośliny kwiatowe, wyd. 3, 895 pp. PAN, Instytut Ochrony Przyrody, Kraków.

Kumar S., Jordan M. C., Datla R. \& Cloutier S. 2013. The LuWD40-1 gene encoding WD repeat protein regulates growth and pollen viability in flax (Linum usitatissimum L.). Plos One Journal 8(7): e69124. doi:10.1371/journal.pone.0069124.

Kuprianova L. A. \& Alyoshina L. A. 1978. Pollen and spores of plants from the flora of European part of the USSR.

2. Lamiaceae-Zygophyllaceae. 184 pp. Akademia Nauk SSSR, Komarov Bot Inst., Leningrad.

Lattar E. C., Galati B., Pire S. \& Ferrucci M. S. 2012a. A comparative ultrastructural study of the pollen of Linum burkatii and L. usitatissimum (Linaceae). J. Torrey Bot. Soc. 139(2): 113-117. http://dx.doi. org/10.3159/TORREY-D-11-00082.1

Lattar E. C., Pire S., Avanza M. M. \& Ferrucci M. S. 2012 b. Pollen analysis in some species of Linaceae-Linoideae from Argentina. Palynology 36(2): 254-263. http:// dx.doi.org/10.1080/01916122.2012.681812.

McDill J., Repplinger M., Simpson B. B. W. \& Kadereit J. W. 2009. The phylogeny of Linum and Linaceae subfamily Linoideae, with implications for their systematics, biogeography, and evolution of heterostyly. Syst. Bot. 34(2): 386-405.

Mirek Z. \& Piękoś-Mirkowa H. 2008. Czerwona Księga Karpat Polskich. Rośliny naczyniowe. 615 pp. W. Szafer Institute of Botany, Polish Academy of Sciences, Kraków.

Mirek Z., Piękoś-Mirkowa H., Zając A. \& Zając M. 2002. Flowering plants and pteridophytes of Poland. A checklist. In: Z. MireK (ed.). Biodiversity of Poland, 1, 442 pp. W. Szafer Institute of Botany, Polish Academy of Sciences, Kraków.

Moroz O. M. \& Tsymbalyuk Z. M. 2005. Palinomorphological characterization of sections Adenolinum, Dasylinum, Linopsis of genus Linum L. in the flora of Ukraine. Ukrain. Bot. Zhurn. 62(5): 666-677.

Ockendon D. J. \& Walters S. M. 2001. Linum L. In: V. H. Heywood, D. H. Valentine, T. G. Tutin \& N. A. Burges (eds.). Flora Europaea, vol. 2, Rosaceae to Umbeliferae, pp. 206-211. Cambridge University Press, Cambridge.

OCKendon D. J. 1971. Cytology and pollen morphology of natural and artificial tetraploids in the Linum perenne group. New Phytol. 70(3): 599-605.
Perveen A. \& QAiser M. 2008. Pollen flora of Pakistan - LIX. Linaceae. Pakistan J. Bot. 40(5): 1819-1822.

Pięroś-Mirkowa H. \& Mirek Z. 2003. Flora Polski. Atlas roślin chronionych. 584 pp. Multico Oficyna Wydawnicza, Warszawa.

PięKoś-Mirkowa H., Mirek Z., ZarębSka E. \& ZaręBSKi M. 2000. Rośliny gór polskich. 248 pp. Muza S.A., Warszawa.

Punt W. \& Den Breejen P. 1981. The northwest European pollen flora, 27. Linaceae. Rev. Palaeobot. Palyno. 33(1-2): 75-115.

Punt W., Hoen P. P., Blackmore S., Nilsson S. \& Thomas A. LE. 2007. Glossary of pollen and spore terminology. Rev. Palaeobot. Palyno. 143: 1-81.

Rogers C. M. \& Xavier K. S. 1972. Parallel evolution in pollen structure in Linum. Grana 12(1): 41-46.

Rogers C. M. \& Xavier K. S. 1971. Pollen morphology as an aid in determining relationships among some widely separated Old-World species of Linum. Grana 11(1): 55-57.

Rogers C. M. 1980. Pollen dimorphism in distylous species of Linum sect. Linastrum (Linaceae). Grana 19: 1920. http://dx.doi.org/10.1080/00173138009424983.

Rogers C. M. 1982. The Systematics of Linum sect. Linopsis (Linaceae). Pl. Syst. Evol. 140: 225-234.

Rogers C. M. 1985. Pollen morphology in Linum sect. Macrantholinum. P1. Syst. Evol. 149: 65-69.

Sneath P. H. A \& Sokal R. R. 1973. Numerical taxonomy: the principles and practice of numerical classification. 573 pp. Freeman, San Francisco.

Stachurska A., Szczypek P. \& SAdowsKa A. 1963. Kartoteka palinologiczna roślin polskich. Linum extraaxillare Kitt. Opolskie Tow. Przyj. Nauk, Zeszyty Przyrod. 5: tab. 38.

Talebi S. M., Sheidai M., Atri M., Sharfinia F. \& NoormoHAMMADI Z. 2012. Palynological study of the genus Linum in Iran (a taxonomic review). Phytol. Balcan. 18(3): 293-303.

Xavier K. S., Milldner R. A. \& Rogers C. M. 1980. Pollen morphology of Linum, sect. Linastrum (Linaceae). Grana 19: 183-188.

Yunus D. \& NAIR P. K. K. 1988. Pollen morphology of Indian Geraniales. Advances in Pollen Spore Research. 168 pp. Today and Tomorrow Printers \& Publishers, New Delhi. 